\title{
An appraisal of oriental theileriosis and the Theileria orientalis complex, with an emphasis on diagnosis and genetic characterisation
}

\author{
Hagos Gebrekidan ${ }^{1} \cdot$ Piyumali K. Perera ${ }^{2} \cdot$ Abdul Ghafar $^{1} \cdot$ Tariq Abbas $^{3} \cdot$ Robin B. Gasser $^{1} \cdot$ Abdul Jabbar ${ }^{1}$ (D)
}

Received: 29 August 2019 / Accepted: 19 November 2019 /Published online: 6 December 2019

(C) Springer-Verlag GmbH Germany, part of Springer Nature 2019

\begin{abstract}
Oriental theileriosis, a tick-borne disease of bovids caused by members of the Theileria orientalis complex, has a worldwide distribution. Globally, at least 11 distinct genotypes of T. orientalis complex, including type 1 (chitose), type 2 (ikeda), type 3 (buffeli), types 4 to 8 , and N1-N3, have been described based on the sequence of the major piroplasm surface protein (MPSP) gene. Of these 11 genotypes, mainly ikeda and chitose are known to be pathogenic and cause considerable morbidity (including high fever, anaemia, jaundice and abortion), production losses and/or mortality in cattle. Mixed infections with two or more genotypes of $T$. orientalis is common, but do not always lead to a clinical disease, posing challenges in the diagnosis of asymptomatic or subclinical forms of oriental theileriosis. The diagnosis of oriental theileriosis is usually based on clinical signs, the detection of piroplasms of $T$. orientalis in blood smears, and/or the use of serological or molecular techniques. This paper reviews current methods used for the diagnosis of $T$. orientalis infections and the genetic characterisation of members of the T. orientalis complex, and proposes that advanced genomic tools should be established for investigations of these and related haemoparasites.
\end{abstract}

Keywords Theileria orientalis $\cdot$ Cattle $\cdot$ Buffalo $\cdot$ Ticks $\cdot$ Diagnosis $\cdot$ Characterisation

\section{Introduction}

Ticks and tick-borne diseases (TBDs) affect the productivity of bovines in tropical and subtropical regions of the world, leading to a significant socioeconomic impact on the livelihood of resource-poor farming communities (Makala et al. 2003). Globally, four main TBDs, namely anaplasmosis (primarily caused by Anaplasma marginale and A. centrale),

Hagos Gebrekidan and Piyumali K. Perera contributed equally to this work.

Section Editor: Panagiotis Karanis

Abdul Jabbar

jabbara@unimelb.edu.au

1 Department of Veterinary Biosciences, Faculty of Veterinary and Agricultural Sciences, The University of Melbourne, Werribee, Victoria, Australia

2 Department of Zoology, Faculty of Science, The University of Peradeniya, Peradeniya 20400, Sri Lanka

3 Department of Epidemiology and Public Health, Cholistan University of Veterinary and Animal Sciences, Bahawalpur, Punjab, Pakistan babesiosis (Babesia bovis, B. bigemina and B. divergens), theileriosis (Theileria annulata, T. parva, T. orientalis complex and others) and heartwater/cowdriosis (Ehrlichia ruminantium) affect bovines, and cause substantial economic losses to cattle industry, particularly in the tropics and subtropics (Makala et al. 2003; Jabbar et al. 2015). The annual global costs of ticks and TBDs to cattle industry are estimated at US\$14 to 19 billion worldwide (de Castro 1997). This impact is higher in developing countries where the costs of tick control and treatment strategies are almost unaffordable for lowincome smallholder farmers (Minjauw and McLeod 2003; Rajput et al. 2006), particularly in many countries of subSaharan Africa, Asia and Latin America (Delgado et al. 1999).

Bovine theilerioses are caused by intracellular protistan parasites of the genus Theileria (Apicomplexa: Piroplasmida; Theileriidae) and are considered as one of the most economically important diseases of bovines globally (Uilenberg 1995). The geographical distribution of Theileria spp. is usually restricted to tropical and subtropical regions where suitable tick vectors occur. Theileria spp. infect primarily domestic and wild ruminants, and cause economically significant diseases in cattle, sheep and goats. For instance, T. annulata and T. parva (the causative agents of tropical or Mediterranean and East Coast 
fever, respectively) are known to be the most pathogenic species in bovines, whereas other species, such as T. mutans, T. taurotragi and members of the T. orientalis complex, often cause asymptomatic infections (cf. Jabbar et al. 2015). Depending on species of Theileria, a number of hard ticks of the genera Amblyomma, Haemaphysalis, Hyalomma and Rhipicephalus can transmit theilerioses.

Traditionally, theileriosis caused by $T$. orientalis complex was considered to be benign and asymptomatic, but clinical cases had been reported from Australia (Rogers and Callow 1966), Japan (Shimizu et al. 1992) and New Zealand (James et al. 1984). However, since 2010, a number of outbreaks of oriental theileriosis have occurred in Australia and New Zealand, leading to significant economic losses in dairy (Perera et al. 2014) and beef (Lane et al. 2015) cattle. Currently, 11 genotypes of $T$. orientalis are recognised, and only ikeda and chitose are known to be pathogenic, causing considerable morbidity and mortality in cattle. The diagnosis of oriental theileriosis can be made using approaches including clinical signs, the detection of piroplasms of $T$. orientalis in blood smears and/or the use of serological or molecular techniques. This article provides an account of oriental theileriosis and then reviews the current methods employed for the diagnosis of oriental theileriosis and the genetic characterisation of $T$. orientalis. It also highlights the need for advanced genomic tools for diagnostic and analytical applications.

\section{The Theileria orientalis complex}

The taxonomy and nomenclature of $T$. orientalis is still unresolved as different names are being used to describe similar parasites from different geographical locations, including T. sergenti from Japan, T. buffeli from Australia and T. orientalis from Europe and elsewhere (Watts et al. 2016). Recently, based on serological and morphological characteristics, Uilenberg (2011) proposed that T. orientalis represented a single species but suggested that it be called a complex. Different molecular markers, including the small subunit (SSU) of nuclear ribosomal RNA (18S rRNA), the first and second internal transcribed spacers (ITS-1 and ITS$2=$ ITS) of nuclear ribosomal DNA, the cytochrome $c$ oxidase III, 23-kDa piroplasm membrane protein (p23) and major piroplasm surface protein $(M P S P)$ genes have been used to study and characterise members of the $T$. orientalis complex (Ota et al. 2009; Altangerel et al. 2011; Kamau et al. 2011a, b; Yokoyama et al. 2011, 2012; Perera et al. 2015a, b, c). Of these markers, the MPSP gene is the most commonly used marker; based on this gene's sequence, at least 11 distinct genotypes of T. orientalis (types 1-8 and N1-N3) from cattle, water buffaloes, sheep and ticks have been reported to date, worldwide (Sivakumar et al. 2014).

\section{Distribution of $T$. orientalis complex}

Oriental theileriosis caused by one or more genotypes of T. orientalis has become an important TBD of bovines, particularly in the Asia-Pacific region (Sivakumar et al. 2014). Recently, the first case of clinical oriental theileriosis was reported in cattle from Virginia, USA (Oakes et al. 2019). Theileria orientalis appears to be widely distributed globally, but in most countries, the genotypic identity of $T$. orientalis complex and the clinical relevance of the distinct genotypes is unclear. To date, $T$. orientalis has been recorded in bovines, sheep, ticks and other blood-feeding insects in more than 40 countries (Sivakumar et al. 2014). However, most reports originate from Japan, followed by Australia, China, Korea and New Zealand.

\section{Life cycle of Theileria orientalis}

The life cycles of Theileria spp. are indirect, involving ticks as vectors. Significant variation occurs in the life cycles of Theileria spp.; some species induce cell transformation and proliferation (e.g., T. parva and T. annulata), whereas others do not (e.g., T. orientalis complex). Generally, Theileria parasites have three distinct stages: (i) schizogony (asexual reproduction), which takes place in vertebrate hosts; (ii) gametogony (sexual reproduction) - the development and union of gametes inside the intestinal cells of tick vectors; and (iii) sporogony (asexual reproduction), which takes place in the salivary glands of tick vectors (Mehlhorn and Schein 1985; Nene et al. 2016). Sporozoites (the infective stage of the parasite) are inoculated with the saliva of a tick when it takes a blood meal from a vertebrate host. These sporozoites invade lymphoid cells and develop into a multinucleate schizont (e.g., in T. annulata) $\sim 24 \mathrm{~h}$ after inoculation. Following merogony/ schizogony, lymphocytes rupture, releasing merozoites which then enter erythrocytes. When a tick feeds on blood from the infected host, infected erythrocytes are ingested. Following ingestion, gametes are released into the gut lumen of the tick, where fertilisation occurs. Fertilisation gives rise to a spherical zygote that invades the gut epithelium of the tick. This zygote develops into motile ookinetes, which then invade the salivary gland of the tick, develop into sporoblasts and multiply asexually, producing thousands of sporozoites. Sporozoites are the infective stage and are injected when infected ticks feed on blood from another vertebrate host, thereby continuing the life cycle (Norval et al. 1992; Shaw 2003).

An ixodid tick, Haemaphysalis longicornis is the main vector of T. orientalis (see Watts et al. 2016). In addition, $H$. bancrofti and H. humerosa are also believed to be potential vectors in Australia (Stewart et al. 1987a, b; Watts et al. 2016). Additionally, other blood-sucking insects, such as March flies (tabanids), mosquitoes or sucking lice are also suggested as 
potential vectors of $T$. orientalis (see Hammer et al. 2015, 2016; Watts et al. 2016). Furthermore, T. orientalis DNA has been detected in other tick species, including Amblyomma variegatum, A. cohaerens, Rhipicephalus decoloratus, R. evertsi and R. praetextatus in Ethiopia (Hornok et al. 2014; Kumsa et al. 2014), as well as from $R$. annulatus ticks in Italy (Toma et al. 2017). However, the competence of these vectors has not been established, as these ticks were collected from cattle, not from pastures, and no experimental infection with T. orientalis from these ticks has been demonstrated to date.

\section{Pathogenesis and economic impact of oriental theileriosis}

For many years, $T$. orientalis was recognised as a benign parasite of bovines (Watts et al. 2016), as its schizonts do not induce cell transformation or lymphoproliferation, unlike T. annulata and T. parva. Although the pathogenesis of $T$. orientalis is not yet completely understood (Watts et al. 2016), a rapid rate of division of both macroschizonts and microschizonts has been observed in calves infected with T. orientalis (Uilenberg et al. 1985), which highlights the potential of members of $T$. orientalis to be categorised as celltransforming pathogens, but this hypothesis requires further testing.

Irrespective of the non-lymphoproliferative nature of $T$. orientalis complex, in the last decade, numerous outbreaks of oriental theileriosis have been recorded in both dairy and beef cattle in the Asia-Pacific region, mainly in Australia and New Zealand (Izzo et al. 2010; Aparna et al. 2011; Islam et al. 2011; Kamau et al. 2011a, b; McFadden et al. 2011; Perera et al. 2013, 2014, 2015c) and, recently, in the USA (Oakes et al. 2019). Based on the characterisation of $T$. orientalis genotypes from cattle affected by clinical oriental theileriosis, only two of the 11 currently known genotypes, namely chitose and ikeda, are known to be pathogenic, and these two genotypes have been found to be associated with hundreds of recent oriental theileriosis outbreaks in Australasia and the USA (Izzo et al. 2010; Islam et al. 2011; McFadden et al. 2011; Perera et al. 2014, 2015c). Most oriental theileriosis outbreaks occurred when cows had been stressed and immunosuppressed due to calving or late pregnancy and/or other associated farm management, nutritional and environmental challenges (reviewed by Watts et al. 2016).

The main economic losses due to oriental theileriosis relate to abortions, significant reduction in milk production (quantity and quality) in dairy cattle, and severe morbidity and mortality rates in affected cattle herds (Perera et al. 2014; Lane et al. 2015).

\section{Diagnosis of oriental theileriosis and genetic characterisation of members of the $T$. orientalis complex}

Various methods have been used for the detection, identification, quantitation and characterisation of $T$. orientalis complex and closely related haemoparasites that infect bovines. The diagnostic methods used for $T$. orientalis can be broadly categorised into traditional and molecular methods.

\section{Traditional methods}

The traditional diagnostic methods used for $\boldsymbol{T}$. orientalis are mainly based on the clinical signs observed in infected cattle, as well as findings of postmortem, microscopic and serological evaluations. Although traditional diagnostic methods might lack sensitivity and specificity, they are still widely used and useful, to support clinical and epidemiological investigations.

Clinical diagnosis Clinical and postmortem examinations assist the diagnosis of oriental theileriosis. Table 1 provides details of the major clinical signs of this disease. The main clinical signs include anorexia, lethargy, pyrexia, haemolytic anaemia, jaundice, pale mucous membranes, haemoglobinuria, increased heart and respiratory rates, nasal discharge, swollen lymph nodes, depression, abortions, reduced production, still birth and death in severe cases (Islam et al. 2011; Izzo et al. 2010; Aparna et al. 2011; McFadden et al. 2011; Eamens et al. 2013a, b; Perera et al. 2014). As a diagnostic method, this approach can provide some information about the disease occurrence in affected herds. Similarly, postmortem examination of suspected cases can also assist in diagnosis. Gross pathological changes observed in oriental theileriosis include jaundice, pale, rounded and enlarged liver, kidney and spleen, haemorrhagic duodenitis, ulcers in the abomasal mucosa, pulmonary oedema and enteritis (Izzo et al. 2010; Aparna et al. 2011; McFadden et al. 2011; Gebrekidan et al. 2015, 2017a). However, both clinical signs and postmortem findings are often subjective, and are not specific to oriental theileriosis, as diseases caused by other blood parasites can cause similar clinical signs or lesions in bovines (Gharbi et al. 2006; Magona et al. 2008).

Microscopic detection of $T$. orientalis The microscopic examination involves the identification of the parasite (piroplasm) in the red blood cells on Giemsa-stained blood smears (Fig. 1) (Aktas et al. 2006a; Khattak et al. 2012; Perera et al. 2013; Chauhan et al. 2015). Microscopy can also be used to estimate the parasite burden (parasitaemia), particularly in clinical cases when a large number of erythrocytes are infected with T. orientalis (see Rogers and Callow 1966; Izzo et al. 2010). However, blood smears are not useful when the parasitaemia is low. Furthermore, it does not allow the discrimination of 
Table 1 Clinical signs associated with oriental theileriosis

\begin{tabular}{|c|c|c|}
\hline Geographical location/region & Clinical signs & References \\
\hline Australia (Queensland) & $\begin{array}{l}\text { Pyrexia }\left(>40.6^{\circ} \mathrm{C}\right) \text {, anaemia, anorexia, haemoglobinuria, } \\
\text { increased heart }(120 / \mathrm{min}) \text {, respiratory rates }(30 / \mathrm{min})\end{array}$ & Rogers and Callow (1966) \\
\hline Australia (New South Wales) & $\begin{array}{l}\text { Pyrexia }\left(>40.6^{\circ} \mathrm{C}\right) \text {, regenerative anaemia or pale } \\
\text { mucous membranes, jaundice, lethargy, tachycardia, } \\
\text { tachypnoea, hyperbilirubinaemia, abortions, still births }\end{array}$ & $\begin{array}{l}\text { Izzo et al. (2010), } \\
\text { Eamens et al. (2013a, b) }\end{array}$ \\
\hline Australia (Victoria) & $\begin{array}{l}\text { Pyrexia, regenerative haemolytic anaemia, hyperglobulinaemia, } \\
\text { pale mucous membranes, anorexia, neutropenia, } \\
\text { leucocytopenia, tachycardia, tachypnoea, abortions }\end{array}$ & Islam et al. (2011) \\
\hline India & $\begin{array}{l}\text { Pyrexia }\left(40.6^{\circ} \mathrm{C}\right) \text {, haemoglobinuria, pale conjunctival } \\
\text { mucosa, lacrimation, nasal discharge, swollen lymph nodes }\end{array}$ & Aparna et al. (2011) \\
\hline Japan & Fever, anaemia, anorexia & Shimizu et al. (1992) \\
\hline New Zealand & Haemolytic anaemia, pale mucous membranes, anorexia, depression, lethargy & McFadden et al. (2011) \\
\hline USA & Weakness, icterus, and anaemia (packed cell volume $12.0 \%$ ) & Oakes et al. (2019) \\
\hline
\end{tabular}

T. orientalis genotypes or other Theileria spp. infecting bovines based on their morphological characteristics. Many Theileria spp. infecting bovines are very similar in their morphology at the piroplasm and schizont stages, except for T. velifera and T. taurotragi which have a unique veil and/or bar-like structures in the infected red blood cells. The main limitations of microscopic examination for T. orientalis include lower specificity, sensitivity, inability to identify T. orientalis to the genotypic level, and the time required to screen blood smears (Aktas et al. 2006b; Izzo et al. 2010; Aparna et al. 2011; Nayel et al. 2012; Perera et al. 2013; Charaya et al. 2016).

Serological methods The immunofluorescence antibody test (IFAT), enzyme-linked immunosorbent assay (ELISA) and latex agglutination test have been employed for the detection of anti-T. orientalis serum antibodies in bovines (Table 2). All these serological tests are targeted at the surface proteins of piroplasms of the parasite(s). Of all available serological

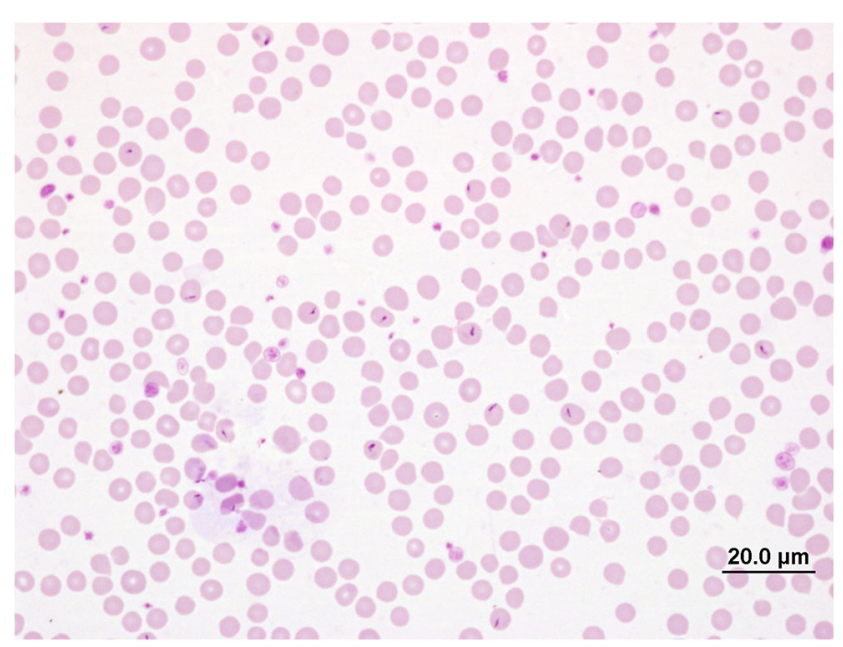

Fig. 1 Giemsa-stained blood smear showing piroplasms of Theileria orientalis in red blood cells of cattle. Photo credit, Dr. Natalie Courtman, Melbourne Veterinary School methods, ELISA is a relatively sensitive technique to study the prevalence of $T$. orientalis infections in cattle populations (not on an individual animal basis). Serological methods are reported to be more sensitive compared to other traditional diagnostic methods (clinical signs, postmortem and microscopic examinations) used for T. orientalis. However, these techniques also have limitations. For example, they are unable to discriminate among different genotypes of $T$. orientalis or differentiate between current and past $T$. orientalis infections, and cross-reactivity with other Theileria spp. is common in serological techniques (Mans et al. 2015). Hence, none of the traditional methods used for $T$. orientalis detection allows the differentiation of known genotypes, or yields genetic information about the parasite(s) present. Thus, molecular methods are crucial to identify and distinguish pathogenic and nonpathogenic genotypes of $T$. orientalis.

\section{Molecular detection and characterisation of $T$. orientalis}

Molecular diagnostic methods can overcome many of the limitations of traditional methods (Conraths and Schares 2006). To date, a number of molecular assays have been utilised to detect, characterise, differentiate and quantitate members of the $T$. orientalis complex, including conventional polymerase chain reaction (PCR), nested-PCR, reverse line blot hybridisation assay (RLB), loop-mediated isothermal amplification (LAMP), real-time/quantitative PCR (qPCR) using hydrolysis probes and multiplexed tandem PCR (MT-PCR) assays (Table 2).

CPCR This technique is widely used to detect and characterise T. orientalis. As compared to traditional diagnostic methods used for T. orientalis, conventional polymerase chain reaction (cPCR) has been shown to achieve higher diagnostic sensitivity (DSe) 
Table 2 Main methods used for the detection and characterisation of Theileria orientalis

\begin{tabular}{|c|c|}
\hline Methods & References \\
\hline \multicolumn{2}{|l|}{ Serological } \\
\hline $\begin{array}{l}\text { Indirect fluorescent antibody test (IFAT) using } \\
\text { piroplasm antigens }\end{array}$ & Uilenberg et al. (1985), Papadopoulos et al. (1996) \\
\hline $\begin{array}{l}\text { Enzyme-linked immunosorbent assay (ELISA) } \\
\text { using piroplasm antigens }\end{array}$ & Shimizu et al. (1988) \\
\hline Latex agglutination test using p33 antigens & Jeong et al. (2005) \\
\hline Indirect ELISA using p33 antigens & Wang et al. (2010a) \\
\hline \multicolumn{2}{|l|}{ Molecular } \\
\hline $\begin{array}{l}\text { Reverse line blot hybridisation (RLB) using } 18 \mathrm{~S} \\
\text { rRNA gene }\end{array}$ & Gubbels et al. (1999) \\
\hline Pan-FRET real-time PCR using cox3 gene & Chaisi et al. (2013) \\
\hline $\begin{array}{l}\text { Conventional PCR using markers } M P S P, p 32 \text {, } \\
\text { p33, p34 and/or } p 23,18 \mathrm{~S} \text { rRNA (SSU) gene }\end{array}$ & $\begin{array}{l}\text { Tanaka et al. (1993), Kawazu et al. (1995), Kubota et al. } \\
\text { (1996), Govaerts et al. (2002), Sarataphan et al. (1999, } \\
\text { 2003), Liu et al. (2010, 2011), Ota et al. (2009), Islam } \\
\text { et al. (2011) }\end{array}$ \\
\hline Semi-nested PCR for $18 \mathrm{~S}$ rRNA & Ghaemi et al. (2012) \\
\hline Nested PCR for ITS-1-5.8S-ITS-2 region & Aktas et al. (2007) \\
\hline $\begin{array}{l}\text { Loop-mediated isothermal amplification } \\
\text { (LAMP) for } p 33 \text { and ITS1-5.8S-ITS2 region }\end{array}$ & Wang et al. (2010b), Liu et al. (2013) \\
\hline Quantitative PCR using ITS- 1 and ITS- 2 regions & Kamau et al. (2011b) \\
\hline $\begin{array}{l}\text { Multiplexed tandem PCR using MPSP, ITS-11 } \\
\text { and } p 23\end{array}$ & Perera et al. (2015a) \\
\hline $\begin{array}{l}\text { Hydrolysis probe-based quantitative PCR using } \\
\text { MPSP }\end{array}$ & Bogema et al. (2015) \\
\hline Multiplexed tandem PCR using MPSP & Gebrekidan et al. (2018) \\
\hline
\end{tabular}

and diagnostic specificity (DSp) using different genetic markers (Perera et al. 2013; Gebrekidan et al. 2016, 2017a, b, c, d; Mans et al. 2015). For this assay, markers including the SSU, MPSP, p23, 32-kDa piroplasm membrane protein (p32), 33-kDa piroplasm membrane protein (p33), 34-kDa piroplasm membrane protein ( $p 34)$, COX-III, $\beta$-tubulin genes, or the ITS have been used to detect, differentiate and characterise $T$. orientalis from different countries (reviewed by Mans et al. 2015). Of these markers, the MPSP gene is the most commonly applied to the T. orientalis complex. The cPCR using MPSP offers the advantage of amplifying relatively long DNA regions from T. orientalis, particularly to characterise novel species/ genotypes for the first time compared with established qPCR assays, which usually only amplify short DNA fragments ( 70-200 base pairs). Limitations of cPCR include its (i) inability to differentiate genotypes in the case of mixed infections with T. orientalis and, (ii) potentially, PCR inhibition due to the presence of different blood constitutes such as haemoglobin and lactoferrin, and other chemicals and reagents used for DNA extraction (Perera et al. 2015a). Furthermore, compared with established qPCR assays used for the detection of T. orientalis (Perera et al. 2015a), cPCR is less sensitive. In addition, in the cPCR assay, post-PCR steps like gel preparation, gel electrophoresis and purification of PCR products for sequencing are costly, laborious and time-consuming. Based on the molecular size of the PCR products on regular agarose gels, it is difficult to discriminate among genotypes of $T$. orientalis complex. To circumvent this issue, mutation scanning technique, such as singlestrand conformation polymorphism (SSCP), has been used to discriminate complex and closely related sequences (from a distinct parasite) even that differ only by a single nucleotide over < 500 bp (cf. Gasser et al. 2006). SSCP has also been used to identify sequence variation within and among genotypes of T. orientalis (see Cufos et al. 2012; Perera et al. 2013). The sensitivity of detection of nucleotide differences depends on the size of PCR products and SSCP conditions (Gasser et al. 2006).

nPCR Members of the Theileria orientalis complex have been detected in cattle blood samples in Brazil, Iran, South Africa, Uganda and the USA using semi-nested or nested PCR (nPCR) assay employing the SSU or ITS loci (Chae et al. 1998; Oura et al. 2011; Ghaemi et al. 2012; Chaisi et al. 2014; Silveira et al. 2016). The principle of $\mathrm{nPCR}$ is similar to that of $\mathrm{cPCR}$, except $\mathrm{nPCR}$ requires two rounds of amplification of the marker(s) using outer and inner primers. The inner primers bind to sequences in the target DNA that are within the DNA fragment amplified by the outer primers. The advantage of this technique is that, if the outer primers bind and amplify non-target regions of the DNA sequence, it is rare that the inner primers will bind within the incorrect regions of the DNA (Odongo et al. 2010). 
A limitation of nPCR can be the higher probability of contamination as the amplicons of the first round of PCR are diluted for the second PCR, and the chance to contaminate the reaction is high which may lead to false-positive results (Cox-Singh et al. 2000). Furthermore, nPCR requires more time (due to the two rounds of amplification) than cPCR (Janardhanan et al. 2014). The estimation of DSe and DSp of nPCR assay is difficult. However, some studies have compared the estimated DSe and DSp of nPCR and with those of cPCR assays, and found that the DSe of the nPCR was higher than that of cPCR. However, due to the higher probability of false-positive results, DSp of nPCR can be lower than that of cPCR (Kim et al. 2008, 2011; Rigotto et al. 2005).

RLB hybridisation RLB hybridisation allows the detection of multiple molecular targets in a sample using one multiplex PCR reaction, followed by probe hybridisation on a nylon membrane. This technique has been used to screen and differentiate several pathogens of veterinary and medical importance (e.g. Rijpkema et al. 1995; Kamerbeek et al. 1997; Gubbels et al. 1999). The development and validation of a novel RLB hybridisation overcomes most of the limitations of cPCR, which lacks the simultaneous detection of pathogens in the same sample, and it is much more sensitive and cheaper than cPCR. In this assay, multiple pathogens can be detected using multiple probes for simultaneous detection. RLB hybridisation was originally developed for the identification of Streptococcus serotypes (Kaufhold et al. 1994). Subsequently, this assay was also used for the detection and differentiation of pathogens in ticks (e.g. Borrelia spirochetes) (Rijpkema et al. 1995), and then rapidly became a standard molecular diagnostic tool for the detection and differentiation of known Theileria and Babesia spp. infecting bovines. For instance, it has been used for the characterisation of Babesia divergens in a human case, and for the discovery of novel Theileria and Babesia spp. (Gubbels et al. 1999; Centeno-Lima et al. 2003; Nijhof et al. 2003; Schnittger et al. 2004; Oura et al. 2004; Brigido et al. 2004; Tomassone et al. 2012). Gubbels et al. (1999) validated an RLB hybridisation assay for the simultaneous detection and differentiation of Theileria and Babesia spp. infecting bovines, and it was able to differentiate six and three Theileria and Babesia spp., respectively. The main limitations of RLB assay include a time-consuming protocol with many steps and its low specificity (Mans et al. 2015).

LAMP LAMP is a simple, sensitive, rapid and cost-effective technique that amplifies different templates, including genomic DNA, heat-treated blood and blood dried on filter papers under isothermal conditions (Notomi et al. 2000; Kuboki et al. 2003; Poon et al. 2006; Thekisoe et al. 2010). This technique is a useful diagnostic method to be employed in laboratories with limited resources. It does not require expensive laboratory equipment, such as PCR thermocyclers and fridges/ refrigerators, and the reagents are stable at room temperature ( 25 to $37^{\circ} \mathrm{C}$ ), which makes this method appropriate for use in field conditions (Thekisoe et al. 2009). Many studies have reported the utility of the LAMP technique for the rapid detection of both Theileria and Babesia spp. infecting bovines (Iseki et al. 2007; Salih et al. 2008; He et al. 2009; Thekisoe et al. 2010; Liu et al. 2012). However, only two studies have reported the use of LAMP for the diagnosis of $T$. orientalis infection in China (Wang et al. 2010; Liu et al. 2013). One of the main limitations of LAMP for T. orientalis is the challenge of designing reliable primers for closely related genotypes (Torres et al. 2011).

qPCR This technique was first described in the mid$1990 \mathrm{~s}$, and its popularity and usage grew in the field of molecular microbiology, as it allowed sensitive, accurate and reproducible detection of pathogens in a variety of samples (Bretagne et al. 2001; Nicolas et al. 2002; Bossolasco et al. 2003; Mary et al. 2004; Vitale et al. 2004). It is a reliable assay to measure gene expression, to quantitate parasite intensity and to undertake single nucleotide polymorphism (SNP) analysis. As compared with other commonly used molecular diagnostic tools, such as cPCR, nPCR, RLB hybridisation and LAMP assays, qPCR is more sensitive and less time-consuming, and, once critically standardised and validated, does not require post-PCR analyses, such as gel electrophoresis and DNA sequencing (Francino et al. 2006; Abda et al. 2011). Another advantage of this assay is that highresolution melt (HRM) curve analysis can be used to infer variation in PCR products. High-resolution melt curve analysis is a rapid, practical and inexpensive technique to discriminate parasites to the species-level based on the melting characteristics of amplicons (Morick et al. 2009; Mehta et al. 2013).

Many studies have evaluated qPCR assay for the detection, identification and quantitation of Theileria spp. infecting bovines globally (Sibeko et al. 2008; Papli et al. 2011; Ros-García et al. 2012; Chaisi et al. 2013). Recently, TaqMan qPCR assays were developed for T. orientalis genotypes, targeting the MPSP gene for use in Australia (Bogema et al. 2015) and in New Zealand (Pulford et al. 2015). These two assays performed similarly, in terms of specificity and sensitivity, but these assays are not able to detect all currently known genotypes of $T$. orientalis or novel genotypes in Australia and New Zealand. Moreover, initial costs linked to the setting up and standardisation of qPCR can be relatively high (e.g., Mackay et al. 2002). Due to the high analytical sensitivity of qPCR assays, sound experimental design, the inclusion of suitable internal controls and data normalisation are crucial to achieving reliable results (Wong and Medrano 2005). 
MT-PCR Various duplex and/or multiplex qPCR assays have been developed for the simultaneous detection of different pathogen species, including Theileria spp. of bovines (Criado-Fornelio et al. 2009; Peleg et al. 2010; Bilgiç et al. 2013; Junlong et al. 2015). An MT-PCR assay was developed for the simultaneous detection of the four common genotypes (buffeli, chitose, ikeda and type 5) of the T. orientalis complex known to occur in Australasia (Perera et al. 2015a). This assay used multiple markers, including the MPSP gene for genotypes chitose and type 5, the p23 gene for buffeli and ITS-1 for ikeda (Perera et al. 2015a). However, subsequently, Gebrekidan et al. (2017d) detected cross-amplification of p23 gene and ITS-1 from both genotypes buffeli and ikeda. Consequently, the MT-PCR assay was modified to detect the four common genotypes (buffeli, chitose, ikeda and type 5) of T. orientalis by using only one marker (i.e. MPSP) in the assay (Gebrekidan et al. 2018). This technique requires the EasyPlex platform (AusDiagnostics Pty. Ltd., Australia), which includes a 24 well-variant of the Easy-Plex Processor, a 96 well-Easy-Plex Analyser, personal computer with Easy-Plex software, vortexer, 96-well plates, dilution plate, plate sealing films and a liquid handling robot. The assay involves primary amplification using primers designed to each of the genotype of $T$. orientalis targeted, and secondary amplification for quantification using nested primers to internal regions of specific markers used. Samples tested in this assay are recorded as testpositive or test-negative using the auto-call function in the Easy-Plex software. Similarly, the intensity of infection (DNA-copy numbers) for each genotype in each sample is determined by comparison with the cycle threshold data predetermined for an internal spike-control containing a known number of DNA copies $(10,000)$ provided by the AusDiagnostics Pty. Ltd., Australia (cf. Perera et al. 2015a). Although this assay is a time- and cost-effective and sensitive method to simultaneously detect multiple genotypes of T. orientalis, it requires specific reagents and equipment, and, thus, can be relatively costly to set up initially.

\section{Considerations regarding individual-animal versus herd-level testing}

Although the currently available advanced molecular diagnostic tools used for $T$. orientalis allow for a rapid and accurate diagnosis (mainly for the two pathogenic genotypes chitose and ikeda), some assays can be expensive for routine use due to individual testing of blood samples, particularly when outbreaks of oriental theileriosis occur in cattle herds. However, herd-level prevalence and intensity of infection with T. orientalis can be readily determined at a considerably low cost by testing pooled blood samples from herds. Several studies have evaluated and reported the usefulness and costeffectiveness of pooled sampling technique for distinct applications. For example, pooled testing has been utilised for the screening of blood samples for malaria from blood donors, the detection of bovine leukaemia and viral diarrhoea pathogens in cattle and Salmonella infections in poultry (Muñoz-Zanzi et al. 2000; Singer et al. 2006; Bharti et al. 2009; Hsiang et al. 2010). Recently, the performance and cost-effectiveness of MTPCR were assessed for the diagnosis of the two pathogenic genotypes (ikeda and chitose) of T. orientalis using pooled blood samples from cattle (Gebrekidan et al. 2017a, b, c, d). Although shown to be useful in this proof of concept study, further experimental optimisation is required before this assay can be routinely used in the monitoring of $T$. orientalis infection(s) in bovine herds.

\section{Conclusions and future implications}

Recent outbreaks of oriental theileriosis in cattle in the AsiaPacific region and the USA have challenged the dogma that oriental theileriosis is a benign infection. Evidence shows that the clinical form of oriental theileriosis can lead to significant economic losses in dairy and beef cattle. Furthermore, the two genotypes (ikeda and chitose) of T. orientalis are mainly linked to the clinical form of oriental theileriosis. The taxonomy and nomenclature of members of the T. orientalis complex are still unresolved, and a number of molecular markers have been utilised to characterise $T$. orientalis from cattle. Various aspects of oriental theileriosis such as transmission, pathogenesis, epidemiology and control remain to be fully explored.

A critical appraisal of the literature shows that the currently available traditional diagnostic methods used for the detection of $T$. orientalis can have limitations, particularly regarding diagnostic and analytical sensitivity and specificity. However, most of the limitations associated with the traditional diagnostic methods used for detection can be overcome by using molecular diagnostic tools. Of the currently available molecular diagnostic tools, cPCR employing the MPSP gene is the most commonly used technique for the characterisation of $T$. orientalis genotypes globally, although other molecular markers, such as $18 \mathrm{~S}$ rRNA, ITS and $p 23$ gene, have also been employed. A few quantitative PCR assays employing different markers have also been developed and validated in Australia and New Zealand to detect, differentiate and quantitate pathogenic genotypes (ikeda and chitose) of T. orientalis (e.g. Bogema et al. 2015; Perera et al. 2015a; Gebrekidan et al. 2018).

Currently available, advanced molecular tools for the diagnosis and characterisation of $T$. orientalis are unable to simultaneously reliably detect/distinguish all of the currently known and/or novel genotypes of $T$. orientalis. Therefore, validation of other molecular tools that can simultaneously detect all currently known and/or novel genotypes of $T$. orientalis is required. It is expected that next-generation sequencing 
(NGS) of PCR amplicons using the Illumina platform will be a suitable method that could allow both infection intensity and genetic diversity within $T$. orientalis populations to be measured directly. Recently, Chaudhry et al. (2019) used 18S rDNA spanning V4 hyper-variable region $(\sim 500$ base pairs) of haemoprotozoa to detect eight and six species of Theileria and Babesia in cattle and buffaloes in Pakistan. Importantly, some of these species were detected for the first time in Pakistan. A similar approach using the MPSP marker could be utilised to detect and quantitate T. orientalis genotypes. Such a NGS-bioinformatic approach could help shed light on the biology, epidemiology and population genetics of members of the $T$. orientalis complex.

Funding information This project was supported by Collaborative Research and Early Career Researchers grants (the University of Melbourne) and Research Initiatives Fund grant (the Faculty of Veterinary and Agricultural Sciences, the University of Melbourne) (A.J.). H.G. and A.G. are grateful recipients of the Melbourne International Research Scholarships (MIRS) and Melbourne International Fee Remission Scholarships (MIFRS) through The University of Melbourne. P.K.P received the International Postgraduate Research Scholarship (IPRS) and Australian Postgraduate Award (APA) through the University of Melbourne. Another support was through funds from the Australian Research Council (ARC).

\section{Compliance with ethical standards}

Conflict of interest The authors declare that they have no conflict of interest.

\section{References}

Abda B, de Monbrison F, Bousslimi N, Aoun K, Bouratbine A, Picot S (2011) Advantages and limits of real-time PCR assay and PCRrestriction fragment length polymorphism for the identification of cutaneous Leishmania species in Tunisia. Trans R Soc Trop Med Hyg 105:17-22

Aktas M, Altay K, Dumanli N (2006a) A molecular survey of bovine Theileria parasites among apparently healthy cattle and with a note on the distribution of ticks in eastern Turkey. Vet Parasitol 138:179185

Aktas M, Altay K, Dumanli N (2006b) PCR-based detection of Theileria ovis in Rhipicephalus bursa adult ticks. Vet Parasitol 140:259-263

Aktas M, Bendele KG, Altay K, Dumanli N, Tsuji M, Holman PJ (2007) Sequence polymorphism in the ribosomal DNA internal transcribed spacers differs among Theileria species. Vet Parasitol 147:221-230

Altangerel K, Battsetseg B, Battur B, Sivakumar T, Batmagnai E, Javkhlan G, Tuvshintulga B, Igarashi I, Matsumoto K, Inokuma H, Yokoyama N (2011) The first survey of Theileria orientalis infection in Mongolian cattle. Vet Parasitol 182:343-348

Aparna M, Ravindran R, Vimalkumar MB, Lakshmanan B, Rameshkumar P, Kumar KGA, Promod K, Ajithkumar S, Ravishankar C, Devada K, Subramanian H, George AJ, Ghosh S (2011) Molecular characterization of Theileria orientalis causing fatal infection in crossbred adult bovines of South India. Parasitol Int 60:524-529
Bharti AR, Letendre SL, Patra KP, Vinetz JM, Smith DM (2009) Malaria diagnosis by a polymerase chain reaction-based assay using a pooling strategy. Am J Trop Med Hyg 81:754-757

Bilgiç HB, Karagenç T, Simuunza M, Shiels B, Tait A, Eren H, Weir W (2013) Development of a multiplex PCR assay for simultaneous detection of Theileria annulata, Babesia bovis and Anaplasma marginale in cattle. Exp Parasitol 133:222-229

Bogema DR, Deutscher AT, Fell S, Collins D, Eamens GJ, Jenkins C (2015) Development and validation of a quantitative PCR assay using multiplexed hydrolysis probes for detection and quantification of Theileria orientalis isolates and differentiation of clinically relevant subtypes. J Clin Microbiol 53:941-950

Bossolasco S, Gaiera G, Olchini D, Gulletta M, Martello L, Bestetti A, Bossi L, Germagnoli L, Lazzarin A, Uberti-Foppa C, Cinque P (2003) Real-time PCR assay for clinical management of human immunodeficiency virus-infected patients with visceral leishmaniasis. J Clin Microbiol 41:5080-5084

Bretagne S, Durand R, Olivi M, Garin J, Sulahian A, Rivollet D, Vidaud M, Deniau M (2001) Real-time PCR as a new tool for quantifying Leishmania infantumin liver in infected mice. Clin Diagn Lab Immunol 8:828-831

Brigido C, da Fonseca IP, Parreira R, Fazendeiro I, do Rosario VE, Centeno-Lima S (2004) Molecular and phylogenetic characterization of Theileria spp. parasites in autochthonous bovines (Mirandesa breed) in Portugal. Vet Parasitol 123:17-23

Centeno-Lima S, Do Rosario V, Parreira R, Maia A, Freudenthal A, Nijhof A, Jongejan F (2003) A fatal case of human babesiosis in Portugal: molecular and phylogenetic analysis. Tropical Med Int Health 8:760-764

Chae J, Lee J, Kwon O, Holman PJ, Waghela SD, Wagner GG (1998) Nucleotide sequence heterogeneity in the small subunit ribosomal RNA gene variable (V4) region among and within geographic isolates of Theileria from cattle, elk and white-tailed deer. Vet Parasitol 75:41-52

Chaisi ME, Janssens ME, Vermeiren L, Oosthuizen MC, Collins NE, Geysen D (2013) Evaluation of a real-time PCR test for the detection and discrimination of Theileria species in the African Buffalo (Syncerus caffer). PLoS One 8:e75827

Chaisi ME, Collins NE, Oosthuizen MC (2014) Phylogeny of Theileria buffeli genotypes identified in the South African buffalo (Syncerus caffer) population. Vet Parasit 204:87-95

Charaya G, Rakha N, Maan S, Kumar A, Kumar T, Jhambh R (2016) Comparative evaluation of polymerase chain reaction assay with microscopy for detection of asymptomatic carrier state of theileriosis in a herd of crossbred cattle. Vet World 9:1039-1042

Chaudhry U, Ali Q, Rashid I, Shabbir MZ, Ijaz M, Abbas M, Evans M, Ashraf K, Morrison I, Morrison L, Sargison ND (2019) Development of a deep amplicon sequencing method to determine the species composition of piroplasm haemoprotozoa. Ticks Tick Borne Dis. https://doi.org/10.1016/j.ttbdis.2019.101276

Chauhan H, Patel B, Bhagat A, Patel M, Patel S, Raval S, Panchasara H, Shrimali M, Patel A, Chandel B (2015) Comparison of molecular and microscopic technique for detection of Theileria annulata from the field cases of cattle. Vet World 8:1370-1373

Conraths FJ, Schares G (2006) Validation of molecular-diagnostic techniques in the parasitological laboratory. Vet Parasitol 136:91-98

Cox-Singh J, Pomrehn AS, Wolfe ND, Rahman HA, Lu HY, Singh B (2000) Sensitivity of the nested-polymerase chain reaction (PCR) assay for Brugia malayi and significance of 'free' DNA in PCRbased assays. Int J Parasitol 30:1177-1179

Criado-Fornelio A, Buling A, Asenzo G, Benitez D, Florin-Christensen M, Gonzalez-Oliva A, Henriques G, Silva M, Alongi A, Agnone A (2009) Development of fluorogenic probe-based PCR assays for the detection and quantification of bovine piroplasmids. Vet Parasitol 162:200-206 
Cufos N, Jabbar A, de Carvalho LM, Gasser RB (2012) Mutation scanning-based analysis of Theileria orientalis populations in cattle following an outbreak. Electrophoresis 33:2036-2040

de Castro JJ (1997) Sustainable tick and tickborne disease control in livestock improvement in developing countries. Vet Parasitol 71: 77-97

Delgado C, Rosegrant M, Steinfeld H, Ehui S, Courbois C (1999) Livestock to 2020: the next food revolution. International Food Policy Research Institute, Washington

Eamens GJ, Bailey G, Gonsalves JR, Jenkins C (2013a) Distribution and temporal prevalence of Theileria orientalis major piroplasm surface protein types in eastern Australian cattle herds. Aust Vet J 91:332340

Eamens GJ, Bailey G, Jenkins C, Gonsalves JR (2013b) Significance of Theileria orientalis types in individual affected beef herds in New South Wales based on clinical, smear and PCR findings. Vet Parasitol 196:96-105

Francino O, Altet L, Sánchez-Robert E, Rodriguez A, Solano-Gallego L, Alberola J, Ferrer L, Sánchez A, Roura X (2006) Advantages of real-time PCR assay for diagnosis and monitoring of canine leishmaniosis. Vet Parasitol 137:214-221

Gasser RB, Hu M, Chilton NB, Campbell BE, Jex AJ, Otranto D, Cafarchia C, Beveridge I, Zhu X (2006) Single-strand conformation polymorphism (SSCP) for the analysis of genetic variation. Nat Protoc 1:3121-3128

Gebrekidan H, Gasser RB, Perera PK, McGrath S, McGrath S, Stevenson MA, Jabbar A (2015) Investigating the first outbreak of oriental theileriosis in cattle in South Australia using multiplexed tandem PCR (MT-PCR). Ticks Tick Borne Dis 6:574-578

Gebrekidan H, Gasser RB, Baneth G, Yasur-Landau D, Nachum-Biala Y, Hailu A, Jabbar A (2016) Molecular characterization of Theileria orientalis from cattle in Ethiopia. Ticks Tick Borne Dis 7:742-747

Gebrekidan H, Nelson L, Smith G, Gasser RB, Jabbar A (2017a) An outbreak of oriental theileriosis in dairy cattle imported to Vietnam from Australia. Parasitology 144:738-746

Gebrekidan H, Gasser RB, Stevenson MA, McGrath S, Jabbar A (2017b) Assessing the performance of multiplexed tandem PCR for the diagnosis of pathogenic genotypes of Theileria orientalis using pooled blood samples from cattle. Mol Cell Probes 31:70-75

Gebrekidan H, Abbas T, Wajid M, Ali A, Gasser RB, Jabbar A (2017c) Molecular characterisation of Theileria orientalis from bovines in Pakistan. Infect Genet Evol 47:19-25

Gebrekidan H, Gasser RB, Jabbar A (2017d) Inadequate differentiation of Theileria orientalis genotypes buffeli and ikeda in an MT-PCR assay using the p23 gene as a marker. J Clin Microbiol 55:641-644

Gebrekidan H, Gasser RB, Stevenson MA, Jabbar A (2018) Multiplexed tandem PCR (MT-PCR) assay using the major piroplasm surface protein gene for the diagnosis of Theileria orientalis infection in cattle. J Clin Microbiol 56:e01661-e01617

Ghaemi P, Hoghooghi-Rad N, Shayan P, Eckert B (2012) Detection of Theileria orientalis in Iran by semi-nested PCR. Parasitol Res 110: 527-531

Gharbi M, Sassi L, Dorchies P, Darghouth MA (2006) Infection of calves with Theileria annulata in Tunisia: economic analysis and evaluation of the potential benefit of vaccination. Vet Parasitol 137:231241

Govaerts M, Verhaert P, Jongejan F, Goddeeris BM (2002) Characterisation of the $33 \mathrm{kDa}$ piroplasm surface antigen of Theileria orientalis/sergenti/buffeli isolates from West Java, Indonesia. Vet Parasitol 104:103-117

Gubbels J, De Vos A, Van der Weide M, Viseras J, Schouls L, De Vries E, Jongejan F (1999) Simultaneous detection of bovine Theileria and Babesia species by reverse line blot hybridization. J Clin Microbiol 37:1782-1789
Hammer JF, Emery D, Bogema DR, Jenkins C (2015) Detection of Theileria orientalis genotypes in Haemaphysalis longicornis ticks from southern Australia. Parasit Vectors 8:229

Hammer JF, Jenkins C, Bogema D, Emery D (2016) Mechanical transfer of Theileria orientalis: possible roles of biting arthropods, colostrum and husbandry practices in disease transmission. Parasit Vectors 9: 34

He L, Zhou YQ, Oosthuizen MC, Zhao JL (2009) Loop-mediated isothermal amplification (LAMP) detection of Babesia orientalis in water buffalo (Bubalus babalis, Linnaeus, 1758) in China. Vet Parasitol 165:36-40

Hornok S, Abichu G, Meli ML, Tánczos B, Sulyok KM, Gyuranecz M, Gönczi E, Farkas R, Hofmann-Lehmann R (2014) Influence of the biotope on the tick infestation of cattle and on the tick-borne pathogen repertoire of cattle ticks in Ethiopia. PLoS One 9:e106452

Hsiang MS, Lin M, Dokomajilar C, Kemere J, Pilcher CD, Dorsey G, Greenhouse B (2010) PCR-based pooling of dried blood spots for detection of malaria parasites: optimization and application to a cohort of Ugandan children. J Clin Microbiol 48:3539-3543

Iseki H, Alhassan A, Ohta N, Thekisoe OM, Yokoyama N, Inoue N, Nambota A, Yasuda J, Igarashi I (2007) Development of a multiplex loop-mediated isothermal amplification (mLAMP) method for the simultaneous detection of bovine Babesia parasites. J Microbiol Methods 71:281-287

Islam MK, Jabbar A, Campbell BE, Cantacessi C, Gasser RB (2011) Bovine theileriosis - an emerging problem in south-eastern Australia? Infect Genet Evol 11:2095-2097

Izzo MM, Poe I, Horadagoda N, De Vos AJ, House JK (2010) Haemolytic anaemia in cattle in NSW associated with Theileria infections. Aust Vet J 88:45-51

Jabbar A, Abbas T, Saddiqi HA, Qamar MF, Gasser RB (2015) Tickborne diseases of bovines in Pakistan: major scope for future research and improved control. Parasit Vectors 8:283

James MP, Saunders BW, Guy LA, Brookbanks EO, Charleston WAG, Uilenberg G (1984) Theileria orientalis, a blood parasite of cattle. First report in New Zealand. New Zeal Vet J 32:154-156

Janardhanan J, Prakash JAJ, Abraham OC, Varghese GM (2014) Comparison of a conventional and nested PCR for diagnostic confirmation and genotyping of Orientia tsutsugamushi. Diagn Microbiol Infect Dis 79:7-9

Jeong W, Kweon CH, Kim JM, Jang H, Paik SG (2005) Serological investigation of Theileria sergenti using latex agglutination test in South Korea. J Parasitol 91:164-169

Junlong L, Li Y, Liu A, Guan G, Xie J, Yin H, Luo J (2015) Development of a multiplex PCR assay for detection and discrimination of Theileria annulata and Theileria sergenti in cattle. Parasitol Res 114:2715-2721

Kamau J, de Vos AJ, Playford M, Salim B, Kinyanjui P, Sugimoto C (2011a) Emergence of new types of Theileria orientalis in Australian cattle and possible cause of theileriosis outbreaks. Parasit Vectors 4:22

Kamau J, Salim B, Yokoyama N, Kinyanjui P, Sugimoto C (2011b) Rapid discrimination and quantification of Theileria orientalis types using ribosomal DNA internal transcribed spacers. Infect Genet Evol 11: 407-414

Kamerbeek J, Schouls L, Kolk A, Van Agterveld M, Van Soolingen D, Kuijper S, Bunschoten A, Molhuizen H, Shaw R, Goyal M (1997) Simultaneous detection and strain differentiation of Mycobacterium tuberculosis for diagnosis and epidemiology. J Clin Microbiol 35: 907-914

Kaufhold A, Podbielski A, Baumgarten G, Blokpoel M, Top J, Schouls L (1994) Rapid typing of group A streptococci by the use of DNA amplification and non-radioactive allele-specific oligonucleotide probes. FEMS Microbiol Lett 119:19-25

Kawazu S, Kamio T, Sekizaki T, Fujisaki K (1995) Theileria sergenti and T. buffeli: polymerase chain reaction-based marker system for 
differentiating the parasite species from infected cattle blood and infected tick salivary gland. Exp Parasitol 81:430-435

Khattak R, Rabib M, Khan Z, Ishaq M, Hameed H, Taqddus A, Faryal M, Durranis S, Gillani Q, Allahyar R (2012) A comparison of two different techniques for the detection of blood parasite, Theileria annulata, in cattle from two districts in Khyber Pukhtoon Khwa Province (Pakistan). Parasite: J Soci Françe Parasitol 19:91-95

Kim HS, Kim DM, Neupane GP, Lee Y, Yang NW, Jang SJ, Jung SI, Park KH, Park HR, Lee CS (2008) Comparison of conventional, nested, and real-time PCR assays for rapid and accurate detection of Vibrio vulnificus. J Clin Microbiol 46:2992-2998

Kim DM, Park G, Kim HS, Lee JY, Neupane GP, Graves S, Stenos J (2011) Comparison of conventional, nested, and real-time quantitative PCR for diagnosis of Scrub typhus. J Clin Microbiol 49:607612

Kuboki N, Inoue N, Sakurai T, Di Cello F, Grab DJ, Suzuki H, Sugimoto C, Igarashi I (2003) Loop-mediated isothermal amplification (LAMP) for detection of African trypanosomes. J Clin Microbiol 38:2778-2780

Kubota S, Sugimoto C, Onuma M (1996) Population dynamics of Theileria sergenti in persistently infected cattle and vector ticks analysed by a polymerase chain reaction. Parasitology 112:437-442

Kumsa B, Signorini M, Teshale S, Tessarin C, Duguma R, Ayana D, Martini M, Cassini R (2014) Molecular detection of piroplasms in ixodid ticks infesting cattle and sheep in western Oromia, Ethiopia. Trop Anim Health Prod 46:27-31

Lane J, Jubb T, Shephard R, Webb-Ware J, Fordyce G (2015) Priority list of endemic diseases for the red meat industries. Project code: B.AHE.0010. Meat and Livestock Australia, Sydney, pp 76-81

Liu Q, Zhou YQ, He GS, Oosthuizen MC, Zhou DN, Zhao JL (2010) Molecular phylogenetic studies on Theileria spp. isolates (China) based on small subunit ribosomal RNA gene sequences. Trop Anim Health Prod 42:109-114

Liu AH, Guan GQ, Liu JL, Liu ZJ, Leblanc N, Li YQ, Gao JL, Ma ML, Niu QL, Ren QY, Bai Q, Yin H, Luo JX (2011) Polymorphism analysis of Chinese Theileria sergenti using allele-specific polymerase chain reaction of the major piroplasm surface protein gene. $\mathrm{J}$ Parasitol 97:116-121

Liu A, Guan G, Du P, Liu Z, Gou H, Liu J, Yang J, Li Y, Ma M, Niu Q, Ren Q, Bai Q, Yin H, Luo J (2012) Loop-mediated isothermal amplification (LAMP) assays for the detection of Theileria annulata infection in China targeting the 18S rRNA and ITS sequences. Exp Parasitol 131:125-129

Liu A, Guan G, Du P, Gou H, Zhang J, Liu Z, Ma M, Ren Q, Liu J, Yang J, Li Y, Niu Q, Bai Q, Yin H, Luo J (2013) Rapid identification and differentiation of Theileria sergenti and Theileria sinensis using a loop-mediated isothermal amplification (LAMP) assay. Vet Parasitol 191:15-22

Mackay IM, Arden KE, Nitsche A (2002) Survey and summary: real-time PCR in virology. Nucleic Acid Res 30:1292-1305

Magona J, Walubengo J, Olaho-Mukani W, Jonsson N, Welburn S, Eisler M (2008) Clinical features associated with seroconversion to Anaplasma marginale, Babesia bigemina and Theileria parva infections in African cattle under natural tick challenge. Vet Parasitol 155: 273-280

Makala LH, Mangani P, Fujisaki K, Nagasawa H (2003) The current status of major tick borne diseases in Zambia. Vet Res 34:27-45

Mans BJ, Pienaar R, Latif AA (2015) A review of Theileria diagnostics and epidemiology. Int J Parasitol: Parasit Wildl 4:104-118

Mary C, Faraut F, Lascombe L, Dumon H (2004) Quantification of Leishmania infantum DNA by a real-time PCR assay with high sensitivity. J Clin Microbiol 42:5249-5255

McFadden AM, Rawdon TG, Meyer J, Makin J, Clough RR, Tham K, Mullner P, Geysen D (2011) An outbreak of haemolytic anaemia associated with infection of Theileria orientalis in naive cattle. New Zeal Vet J 59:79-85
Mehlhorn H, Schein E (1985) The piroplasms: life cycle and sexual stages. Adv Parasitol 23:37-103

Mehta B, Daniel R, McNevin D (2013) High resolution melting (HRM) of forensically informative SNPs. Forensic Sci Int: Genet Suppl Series 4:e376-e377

Minjauw B, Mcleod A (2003) Tick-borne diseases and poverty. The impact of ticks and tick-borne diseases on the livelihoods of smallscale and marginal livestock owners in India and eastern and southern Africa. Research report, DFID Animal Health Programme, Centre for Tropical Veterinary Medicine, University of Edinburgh, UK

Morick D, Baneth G, Avidor B, Kosoy MY, Mumcuoglu KY, Mintz D, Eyal O, Goethe R, Mietze A, Shpigel N, Harrus S (2009) Detection of Bartonella spp. in wild rodents in Israel using HRM real-time PCR. Vet Microbiol 139:293-297

Muñoz-Zanzi CA, Johnson WO, Thurmond MC, Hietala SK (2000) Pooled sample testing as a herd screening tool for detection of bovine viral diarrhea virus persistently infected cattle. J Vet Diagn Investig 12:195-203

Nayel M, El-Dakhly KM, Aboulaila M, Elsify A, Hassan H, Ibrahim E, Salama A, Yanai T (2012) The use of different diagnostic tools for Babesia and Theileria parasites in cattle in Menofia, Egypt. Parasitol Res 111:1019-1024

Nene V, Kiara H, Lacasta A, Pelle R, Svitek N, Steinaa L (2016) The biology of Theileria parva and control of East Coast fever-current status and future trends. Ticks Tick Borne Dis 7:549-564

Nicolas L, Prina E, Lang T, Milon G (2002) Real-time PCR for detection and quantitation of Leishmania in mouse tissues. J Clin Microbiol 40:1666-1669

Nijhof AM, Penzhorn BL, Lynen G, Mollel JO, Morkel P, Bekker CP, Jongejan F (2003) Babesia bicornis sp. nov. and Theileria bicornis sp. nov.: tick-borne parasites associated with mortality in the black rhinoceros (Diceros bicornis). J Clin Microbiol 41:2249-2254

Norval RA, Perry BD, Young AS (1992) The epidemiology of theileriosis in Africa. Academic Press Inc, London

Notomi T, Okayama H, Masubuchi H, Yonekawa T, Watanabe K, Amino N, Hase T (2000) Loop-mediated isothermal amplification of DNA. Nucleic Acids Res 28:E63

Oakes VJ, Yabsley MJ, Schwartz D, LeRoith T, Bissett C, Broaddus C, Schlater JL, Todd SM, Boes KM, Brookhart M, Lahmers KK (2019) Theileria orientalis ikeda genotype in cattle, Virginia, USA. Emerg Infect Dis 25:1653-1659

Odongo DO, Sunter JD, Kiara HK, Skilton RA, Bishop RP (2010) A nested PCR assay exhibits enhanced sensitivity for detection of Theileria parva infections in bovine blood samples from carrier animals. Parasitol Res 106:357-365

Ota N, Mizuno D, Kuboki N, Igarashi I, Nakamura Y, Yamashina H, Hanzaike T, Fujii K, Onoe S, Hata H, Kondo S, Matsui S, Koga M, Matsumoto K, Inokuma H, Yokoyama N (2009) Epidemiological survey of Theileria orientalis infection in grazing cattle in the eastern part of Hokkaido, Japan. J Vet Med Sci 71:937944

Oura C, Bishop R, Wampande E, Lubega G, Tait A (2004) Application of a reverse line blot assay to the study of haemoparasites in cattle in Uganda. Int J Parasitol 34:603-613

Oura C, Tait A, Asiimwe B, Lubega G, Weir W (2011) Haemoparasite prevalence and Theileria parva strain diversity in Cape buffalo (Syncerus caffer) in Uganda. Vet Parasitol 175:212-219

Papadopoulos B, Perié NM, Uilenberg G (1996) Piroplasms of domestic animals in the Macedonia region of Greece. 1. Serological crossreactions. Vet Parasitol 63:41-56

Papli N, Landt O, Fleischer C, Koekemoer JO, Mans BJ, Pienaar R, Josemans A, Zweygarth E, Potgieter F, Latif AA (2011) Evaluation of a TaqMan real-time PCR for the detection of Theileria parva in buffalo and cattle. Vet Parasitol 175:356-359 
Peleg O, Baneth G, Eyal O, Inbar J, Harrus S (2010) Multiplex real-time qPCR for the detection of Ehrlichia canis and Babesia canis vogeli. Vet Parasitol 173:292-299

Perera PK, Gasser RB, Anderson GA, Jeffers M, Bell CM, Jabbar A (2013) Epidemiological survey following oriental theileriosis outbreaks in Victoria, Australia, on selected cattle farms. Vet Parasitol 197:509-521

Perera PK, Gasser RB, Firestone SM, Anderson GA, Malmo J, Davis G, Beggs DS, Jabbar A (2014) Oriental theileriosis in dairy cows causes a significant milk production loss. Parasit Vectors 7:467

Perera PK, Gasser RB, Firestone SM, Smith L, Roeber F, Jabbar A (2015a) Semiquantitative multiplexed tandem PCR for detection and differentiation of four Theileria orientalis genotypes in cattle. J Clin Microbiol 53:79-87

Perera PK, Gasser RB, Jabbar A (2015b) Assessment of sequence variability in a 23 gene region within and among three genotypes of the Theileria orientalis complex from south-eastern Australia. Ticks Tick Borne Dis 6:123-128

Perera PK, Gasser RB, Pulford DJ, Stevenson MA, Firestone SM, McFadden AMJ, Jabbar A (2015c) Comparison of the performance of three PCR assays for the detection and differentiation of Theileria orientalis genotypes. Parasit Vectors 8:192

Poon LLM, Wong BWY, Ma EHT, Chan KH, Chow LMC, Abeyewickreme W, Tangpukdee N, Yuen KW, Guan Y, Looareesuwan S, Malik Peiris JS (2006) Sensitive and inexpensive molecular test for falciparum malaria: detecting Plasmodium falciparum DNA directly from heat-treated blood by loopmediated isothermal amplification. Clin Chem 52:303-306

Pulford DJ, Gias E, Bueno IM, McFadden AMJ (2015) Developing high throughput quantitative PCR assays for diagnosing Ikeda and other Theileria orientalis types common to New Zealand in bovine blood samples. New Zeal Vet J 64:29-37

Rajput ZI, Hu S, Chen WJ, Arijo AG, Xiao CW (2006) Importance of ticks and their chemical and immunological control in livestock. J Zhejiang Univ Sci B 7:912-921

Rigotto C, Sincero T, Simoes C, Barardi C (2005) Detection of adenoviruses in shellfish by means of conventional-PCR, nested-PCR and integrated cell culture PCR (ICC/PCR). Water Res 39:297-304

Rijpkema S, Molkenboer M, Schouls LM, Jongejan F, Schellekens J (1995) Simultaneous detection and genotyping of three genomic groups of Borrelia burgdorferi sensu lato in Dutch Ixodes ricinus ticks by characterization of the amplified intergenic spacer region between 5S and 23S rRNA genes. J Clin Microbiol 33:3091-3095

Rogers RJ, Callow LL (1966) Three fatal cases of Theileria mutans infection. Aust. Vet J 42:42-46

Ros-García A, Nicolás A, García-Pérez AL, Juste RA, Hurtado A (2012) Development and evaluation of a real-time PCR assay for the quantitative detection of Theileria annulata in cattle. Parasit Vectors 5: 171

Salih D, Liu Z, Bakheit M, Ali A, El Hussein A, Unger H, Viljoen G, Seitzer U, Ahmed J (2008) Development and evaluation of a loopmediated isothermal amplification method for diagnosis of tropical theileriosis. Transbound Emerg Dis 55:238-243

Sarataphan N, Nilwarangkoon S, Tananyutthawongese C, Kakuda T, Onuma M, Chansiri K (1999) Genetic diversity of major piroplasm surface protein genes and their allelic variants of Theileria parasites in Thai cattle. J Vet Med Sci 61:991-994

Sarataphan N, Kakuda T, Chansiri K, Onuma M (2003) Survey of benign Theileria parasites of cattle and buffaloes in Thailand using allelespecific polymerase chain reaction of major piroplasm surface protein gene. J Vet Med Sci 65:133-135

Schnittger L, Yin H, Qi B, Gubbels MJ, Beyer D, Niemann S, Jongejan F, Ahmed JS (2004) Simultaneous detection and differentiation of Theileria and Babesia parasites infecting small ruminants by reverse line blotting. Parasitol Res 92:189-196
Shaw MK (2003) Cell invasion by Theileria sporozoites. Trends Parasitol 19:1-5

Shimizu S, Suzuki K, Nakamura K, Kadota K, Fujisaki K, Ito S, Minami $T$ (1988) Isolation of Theileria sergenti piroplasms from infected erythrocytes and development of an enzyme-linked immunosorbent assay for serodiagnosis of $T$. sergenti infections. Res Vet Sci 45:206212

Shimizu S, Yoshiura N, Mizomoto T, Kondou Y (1992) Theilleria sergenti infection in dairy cattle. J Vet Med Sci 54:375-377

Sibeko KP, Oosthuizen MC, Collins NE, Geysen D, Rambritch NE, Latif AA, Groeneveld HT, Potgieter FT, Coetzer JA (2008) Development and evaluation of a real-time polymerase chain reaction test for the detection of Theileria parva infections in Cape buffalo (Syncerus caffer) and cattle. Vet Parasitol 155:37-48

Silveira JAG, de Oliveira CHS, Silvestre BT, Albernaz TT, Leite RC, Barbosa JD, Oliveira CMC, Ribeiro MFB (2016) Molecular assays reveal the presence of Theileria spp. and Babesia spp. in Asian water buffaloes (Bubalus bubalis, Linnaeus, 1758) in the Amazon region of Brazil. Ticks Tick Borne Dis 7:1017-1023

Singer RS, Cooke CL, Maddox CW, Isaacson RE, Wallace RL (2006) Use of pooled samples for the detection of Salmonella in feces by polymerase chain reaction. J Vet Diagn Investig 18:319-325

Sivakumar T, Hayashida K, Sugimoto C, Yokoyama N (2014) Evolution and genetic diversity of Theileria. Infect Genet Evol 27:250-263

Stewart NP, Devos AJ, McGregor W, Shiels I (1987a) Haemaphysalis humerosa, not Haemaphysalis longicornis, is the likely vector of Theileria buffeli in Australia. Aust Vet J 64:280-282

Stewart NP, Devos AJ, Shiels I, McGregor W (1987b) The experimental transmission of Theileria buffeli of cattle in Australia by Haemaphysalis humerosa. Aust Vet J 64:81-83

Tanaka MA, Onoe S, Matsuba T, Katayama S, Yamanaka M, Yonemichi H, Hiramatsu K, Baek BK, Sugimoto C, Onuma M (1993) Detection of Theileria sergenti infection in cattle by polymerase chain reaction amplification of parasite-specific DNA. J Clin Microbiol 31:2565-2569

Thekisoe OMM, Bazie RSB, Coronel-Servian AM, Sugimoto C, Kawazu S, Inoue N (2009) Stability of loop-mediated isothermal amplification (LAMP) reagents and its amplification efficiency on crude trypanosome DNA templates. J Vet Med Sci 71:471-475

Thekisoe OM, Rambritch NE, Nakao R, Bazie RS, Mbati P, Namangala B, Malele I, Skilton RA, Jongejan F, Sugimoto C (2010) Loopmediated isothermal amplification (LAMP) assays for detection of Theileria parva infections targeting the PIM and p150 genes. Int $\mathrm{J}$ Parasitol 40:55-61

Toma L, Di Luca M, Mancini F, Severini F, Mariano C, Nicolai G, Laghezza Masci V, Ciervo A, Fausto AM, Caccio SM (2017) Molecular characterization of Babesia and Theileria species in ticks collected in the outskirt of Monte Romano, Lazio Region, Central Italy. Ann Ist Super Sanita 53:30-34

Tomassone L, Grego E, Callà G, Rodighiero P, Pressi G, Gebre S, Zeleke B, Meneghi D (2012) Ticks and tick-borne pathogens in livestock from nomadic herds in the Somali region, Ethiopia. Exp Appl Acarol 56:391-401

Torres C, Vitalis EA, Baker BR, Gardner SN, Torres MW, Dzenitis JM (2011) LAVA: an open-source approach to designing LAMP (loopmediated isothermal amplification) DNA signatures. BMC Bioinformatics 12:240

Uilenberg G, Perié NM, Spanjer AA, Franssen FF (1985) Theileria orientalis, a cosmopolitan blood parasite of cattle: demonstration of the schizont stage. Res Vet Sci 38:352-360

Uilenberg G (1995) International collaborative research: significance of tick-borne hemoparasitic diseases to world animal health. Vet Parasitol 57:19-41

Uilenberg G (2011) Theileria sergenti. Vet Parasitol 175:386 
Vitale F, Reale M, Vitale E, Petrotta E, Torina A, Caracappa S (2004) TaqMan-based detection of Leishmania infantum DNA using canine samples. Ann N Y Acad Sci 1026:139-143

Wang LX, Zhao JH, He L, Liu Q, Zhou DN, Zhou YQ, Zhao JL (2010a) An indirect ELISA for detection of Theileria sergenti antibodies in water buffalo using a recombinant major piroplasm surface protein. Vet Parasitol 170:323-326

Wang LX, He L, Fang R, Song QQ, Tu P, Jenkins A, Zhou YQ, Zhao JL (2010b) Loop-mediated isothermal amplification (LAMP) assay for detection of Theileria sergenti infection targeting the p33 gene. Vet Parasitol 171:159-162

Watts J, Playford M, Hickey K (2016) Theileria orientalis: a review. New Zeal Vet J 64:3-9

Wong ML, Medrano JF (2005) Real-time PCR for mRNA quantitation. BioTech 39:75-85
Yokoyama N, Ueno A, Mizuno D, Kuboki N, Khukhuu A, Igarashi I, Miyahara T, Shiraishi T, Kudo R, Oshiro M, Zakimi S, Sugimoto C, Matsumoto K, Inokuma H (2011) Genotypic diversity of Theileria orientalis detected from cattle grazing in Kumamoto and Okinawa prefectures of Japan. J Vet Med Sci 73:305-312

Yokoyama N, Sivakumar T, Ota N, Igarashi I, Nakamura Y, Yamashina H, Matsui S, Fukumoto N, Hata H, Kondo S, Oshiro M, Zakimi S, Kuroda Y, Kojima N, Matsumoto K, Inokuma H (2012) Genetic diversity of Theileria orientalis in tick vectors detected in Hokkaido and Okinawa, Japan. Infect Genet Evol 12:1669-1675

Publisher's note Springer Nature remains neutral with regard to jurisdictional claims in published maps and institutional affiliations. 